\title{
WALT WHITMAN AND THE TRIMBLES: NEW ZEALAND, THE FIRST CONCORDANCE OF LEAVES OF GRASS, AND THE DUNEDIN PUBLIC LIBRARY
}

\author{
Joel Myerson
}

I FIRST BECAME AWARE of the Dunedin Public Library's superb Trimble Collection of Walt Whitman when I read Betty Randle's 1975 catalogue of it in 1989, while working on my bibliography of Whitman's writings. ${ }^{1}$ My wife and I were about to take the first of our many trips to New Zealand that year, and I thought that I could spend an hour or two at the Trimble Collection to see if any books were of interest. The couple hours turned into a full day and a number of the books I examined appear in my bibliography with the Dunedin Public Library listed as the only known location for them among the some thirty libraries that I visited, including all the major American ones, and institutions in Canada, Scotland, Ireland, and England. Indeed, there are a few works that are still unique-I have yet to see another copy of them. The story of the people responsible for this collection-as well as for the first complete concordance to Whitman's writings - is a fascinating one of Kiwi-AngloAmerican connections. ${ }^{2}$

William Heywood Trimble was born near Liverpool, England, on January $21,1860 .{ }^{3} \mathrm{He}$ was the son of Robert Trimble, who emigrated to New Plymouth, New Zealand, in 1875 because of pressing money problems at home. Although his father was never financially successful, he served in Parliament representing Taranaki (1879-1887), was appointed a judge, and in one obituary was referred to as "Colonel Trimble," a "North Island pioneer." William placed third in the nation in the Junior Civil Service Examination and joined the Land Office. He married Henrietta (Hetty) Penn in July 1885, and in January 1887 they had their first and only child, Dorothy. Much of Trimble's early career was spent in public service, first in New Plymouth, Wellington, and Gisborne, and then, in 1898, Dunedin. His wife died in 1897 and he married Annie Eliza Nelson in Dunedin in May 1899. By November 1901 he transferred to the new Department of Roads, but in 1909 he was made redundant. 
Trimble must have had bookish leanings, not just because he did so well in the Civil Service Examination, but because after leaving the Department of Roads he opened a book shop in Dunedin. One year later, in 1910, he became Librarian of the Hocken Library (now at the University of Otago), formed by a local doctor, Thomas Morland Hocken, for the stated purpose of "the acquisition of books, newspapers, maps, pamphlets, photographs, pictures and artifacts relating to New Zealand, the Pacific and early Australia."4 His wife Annie wrote seven articles on the collections for the Dunedin Evening Star in 1910, ${ }^{5}$ but, sadly, she died the following year. Trimble prepared a catalogue

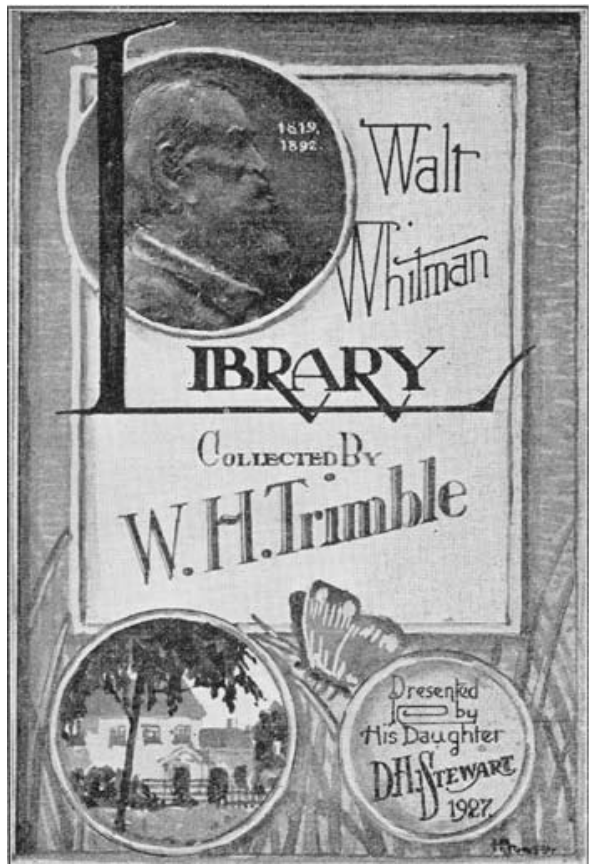
of the Hocken Library and, upon its publication in 1912, his appointment ended. ${ }^{6} \mathrm{He}$ established his own second-hand book store, using his books (except, of course, the Whitman items), as his first stock; ${ }^{7}$ then he worked in Driver's and Newbold's bookshops, and later at the Otekaike Boys' Home. William Heywood Trimble died on July 12, 1927. Dorothy, by now Mrs. J. W. Stewart, was responsible for the Trimble Collection coming to the Dunedin Public Library. Her death in 1974 at age eighty-seven brought to a close nearly eighty years of the Trimbles' involvement with Whitman and Dunedin.

There is nothing in Trimble's background to suggest a particular interest in Whitman, though much to indicate his love of learning; indeed, one obituary commented that "his scholarship was wide and systematic." 8 His work at the Hocken Library led to the 1912 Catalogue and a small self-published pamphlet, Dr Hocken and His Historical Collection, but Trimble's only other documented literary interest seems to have been William Shakespeare, about whom he self-published two small pamphlets, Notes from a Lecture on Shakespeare and the Merchant of Venice and Shakespeare's Ancient Pistol. ${ }^{9}$ Fortunately, he himself has told the story of how he first came upon Whitman's writings:

One day, towards the end of 1896, a friend gave me Stead's Penny Poet selection from Leaves of Grass. ${ }^{10} \mathrm{He}$ asked: What do you think of this? I replied: Oh, Whitman, but Whitman couldn't write poetry. He responded:Well, promise me you will read this: then tell me what you think of it. I read the booklet through, carefully and conscientiously, 
several times, but failed to derive any satisfaction from it. Rhyme? Very scarce. Meters? None whatever. Rhythm? Imperceptible. And no sense either. I could find nothing but a mere barbarous jangle of words. But a few weeks later, when returning the little volume to its place, I happened to open it at random, perhaps with something of the carelessness of dislike, and caught sight of this line: "And the running blackberry would adorn the parlors of heaven." This line, to some extent, gave me a key to Whitman's writings. ${ }^{11}$

Later, as his daughter tells the story, he "bought the Chatto \& Windus selection, then the Canterbury Poets selection. In 1897 he bought a biography of the poet and this was the modest beginning of this Trimble Collection which he brought with him to Dunedin in 1898." 12

Having once discovered Whitman, though, Trimble devoted himself to the poet's cause. He lectured "almost extempore" on Whitman before the Gisborne Mutual Improvement Society in May 1897 and was "well received (with - of course-some vile abuse)," and for an hour on Leaves of Grass before the Theosophical Society in Dunedin on January 22,1899 , where, according to a report, he described the book as "one of the most original literary performances of the nineteenth century," and called Whitman "one of the most remarkable individualities the present age has produced." 13 As the new century opened, he began publishing on Whitman, usually articles defending the poet from his attackers, such as in a letter he wrote Havelock Ellis complaining of his picture of Whitman: "I cannot understand how any sane reader of Whitman would glorify him as an invert." 14

In the winter of 1903 Trimble gave a series of three lectures on Whitman, which he collected and published in 1905 as Walt Whitman and Leaves of Grass. ${ }^{15}$ In one hundred pages, Trimble attempted a fair assessment of Whitman's major work, one that recognized the poet's originality as well as some of his faults. He found three major themes in Leaves - "Human Freedom," "Human Brotherhood," and "Death and Immortality" (24) — which contributed to Trimble's belief that "all [Whitman] asks of man is that he realise his own inherent nobleness" (49). Trimble praised Whitman for breaking new ground in literature: "In his style of writing Whitman had little or nothing in common with either contemporary poets or those of previous times; for he abandoned the time-honoured customs of rhyme and metre, leaving his works to find their own rhythm" (18). Nevertheless, there are problems with Whitman's style:

In his mannerWhitman is occasionally obscure; in much of his earlier work there is an arrogant, even insolent, note, which the reader is apt to find rather irritating; and in some of his poems he inserted long catalogues of occupations, articles, and so forth, which are rather trying to the reader's patience. Also, he frequently uses uncouth expressions; and at times he even goes so far as to manufacture words. . . .

Whitman's punctuation, also, is open to hostile criticism; he evidently had but a faint conception of the use and value of the semicolon; his perpetual commas lead the reader into confusion, and add to the difficulty of getting at his meanings; and his use of the 
parenthesis is much too frequent. His inspiration was intermittent; and often, in attempting to be forcible in his language, he only succeeded in being feeble. (20-21)

The book was well-received, being favorably reviewed ("a skilful and generous" work) by Horace Traubel and the Irish writer Edward Dowden, who called the book "not only sympathetic but sane."16

All of this brought Trimble a degree of regional fame. He corresponded about Whitman with the Australian writer Bernard O'Dowd for a number of years. ${ }^{17}$ Both Trimbles corresponded with many of the major Whitman collectors of the time, including Traubel, who wrote Trimble that his book made him "feel somehow as if I was shaking hands with you around the globe." ${ }^{18}$ And in 1915, when tributes to Whitman were solicited from the best-known Whitman scholars and collectors in the world for publication in a book, both Annie and William Trimble were asked to and did contribute. ${ }^{19}$

Annie Trimble herself wrote Walt Whitman and Mental Science, a fifteen-page pamphlet published in 1911, in which she "asks" Whitman questions about such topics as personality, death, egotism, and unity, and he "replies" by using quotations from his writings. ${ }^{20}$ In 1912, William self-published a catalogue of his Whitman collection, a thirty-six-page pamphlet listing copies of Whitman's writings, as well as newspaper and magazine articles, books, and chapters in books about him. ${ }^{21}$ It was dedicated to Edwin James Brady, an Australian journalist and poet, whose copy bears his notation that the book's author was a "remarkably bookish man and a pleasing critical writer"; moreover, as "a profound admirer of Whitman," he had "done the spirit of the Great American justice-with understanding - in his little volume." 22 And for the centenary celebration of Whitman's birth in 1919, William wrote an appreciation in the Dunedin Evening Star, in which he said that to "adequately criticise Whitman appears to be extremely difficult" because it "seems almost impossible to avoid trespassing into extravagant praise on the one hand or futile depreciation on the other." His conclusion is prescient: "The most valuable criticism of Walt Whitman's work should appear in 1955, the centennial of the first issue of 'Leaves of Grass,' which are as yet but 64 years old. The world will then judge how they have stood the test of time, or, as Walt himself wrote: Whether we shall be victorious or utterly quell'd and defeated." 23

Together, Annie and William Trimble are best known for their concordance to Leaves of Grass. ${ }^{24}$ In fact, their house in Dunedin was called "Concord" for these reasons: there was no discord there, they wished to affectionately remember the Concord circle of authors (and especially Bronson Alcott), and they were always concording. The story of how this concordance was produced is a tale of dedication and, ultimately, desire thwarted. 
William began concording Whitman in 1903 or 1904 and, after several false starts ending when he consigned his papers to the fire, he had about eighty pages completed. In 1904, he wrote Whitman's biographerWilliam Sloan Kennedy that he was working on the concordance. Kennedy conveyed this information to Isaac Hull Platt, who had just published a book on Whitman. ${ }^{25}$ Platt replied that he had completed about one hundred pages of his own concordance, ${ }^{26}$ which, in turn, caused Trimble to yet again burn what he had compiled. Platt and Trimble agreed to work together, Platt continuing on from the front, and Trimble working backwards from the end, the two eventually meeting somewhere in the middle. Trimble was not at all happy with this arrangement, though, for he considered the first part of Leaves far more interesting and universal than the latter part, which he thought more personal. Annie joined the project and when they reached the middle of the book, they wrote Platt of their success. But Platt responded that he had been unable to go beyond the pages he had already concorded, and he asked the Trimbles to finish the work on their own. In a few weeks, he shipped off forty or fifty pounds of materials, including some three cubic feet of notes, telling the Trimbles that they "should have the whole credit of the work" because all he cared about was to "see it done." ${ }^{27}$ The Trimbles added this to what they had already completed, and finished the remaining pages themselves, concluding this portion of the work in January 1907.

Work on the concordance was painstaking, in part because it printed not just the location of the word concorded, but also the full line in which it appeared. In doing this by hand, a sheet of paper was used for each line of verse, with the letters of the alphabet printed in a column on the left and the words in that line of verse listed next to the letters with which they began. These words (and the line in which they appear) were then transferred to sheets of paper on which previous occurrences of the word had been written. That is, a line of verse with eleven terms to be concorded required that line to be written twelve times, once on the initial index sheet and then eleven more times when entered on the individual word sheets. (This took a lot of paper, and Annie remarked that their monthly bills for paper were at least five times as large as their butcher's bills; and once, when she told this to a friend, to Annie's surprise, her friend's "horror was so voluble and overwhelming that there was no opportunity to explain that we were vegetarians, though not of the bigoted variety.") The typing of the concordance from handwritten notes remained, and this was done off-and-on for another two years until, finally, on May 31, 1909-coincidentally, Whitman's birthday-Annie Trimble, in her husband's words, “'drove the last spike,' by typing the figure 8."

The resulting concordance was numerically impressive, as William 
made clear. As appropriate to someone who had been employed by the Department of Roads, he summarized the task in a series of daunting statistics: the notes occupied five cubic feet; the typed copy took up 1,333 pages; there are 61,201 entries in the concordance; and 13,447 separate words were concorded, of which 6,978 were used only once.

In July 1909 Trimble sent a typed copy of the concordance to Platt, who shared it with Traubel. Another of Whitman's literary executors, Thomas Harned, took over the "business end of the thing," unsuccessfully approached D. Appleton and Company, publishers of many works by Whitman, and, finally, suggested publishing by subscription. ${ }^{28}$ But matters began to fall apart when Harned withdrew, possibly, according to Platt, out of pique because he had not been approached first by Trimble; still, Platt had put together $\$ 750$ : $\$ 400$ from the Carnegie Institution of Washington, $\$ 100$ from himself, and $\$ 250$ from anonymous donors. ${ }^{29}$ Platt's increasing ill health (he would die in August 1912) kept him from further promoting the concordance, and at some point he approached the great Toronto Whitman collector Henry S. Saunders.

Saunders and Trimble were soon engaged in a spirited correspondence about the concordance and how best to get it published. ${ }^{30}$ After Saunders received the concordance from Platt's widow on November 13, 1912, he began thinking about publishers, including Mitchell Kennerley (who would publish Prose Works and Leaves of Grass in 1914). Traubel approached Kennerley, but apparently never received an answer. Traubel was concerned, though, because he thought it "a big and costly job" that would have to be done "for some other than a market reason," and he proposed publishing by subscription. ${ }^{31}$ The British publisher J. M. Dent also passed on it. ${ }^{32}$ Remembering that Platt had obtained money from the Carnegie Institution, Saunders tried as well, but he was rebuffed twice, in 1915 because they had just funded concordances for Keats and Spencer, and in 1919 because the war had left the group in a "straitened financial condition." ${ }^{33}$ Most of their remaining correspondence deals with Whitman matters in general, or personal discussions, not with the concordance.

Soon after 1930, when Saunders sold his collection to Brown University, ${ }^{34}$ he must have approached Brown about publishing the concordance, because in 1932 he thanked the Trimbles' daughter, Dorothy Stewart, for granting him permission to print it "without royalties." ${ }^{35}$ The people at Brown tried to work the concordance into shape for publication but, as Henry B. Van Hoesen, the Brown librarian, wrote Stewart in 1946 , there was no one on their staff able "to do the necessary reworking of the manuscript for publication," nor was there money in hand to do the publication if the work could be done. ${ }^{36}$ (In fact, Gay Wilson Allen later wrote Stewart that Brown was "about to employ" him to check over the concordance but the negotiations fell through because they said they 
could not get the needed funds to publish it.) $)^{37}$ Van Hoesen had heard about a similar project underway at the University of Washington, and wrote a colleague there, who passed his letter on to Edwin Harold Eby in the English department. Eby wrote Van Hoesen that he had known about the Trimbles' concordance "for a long time" but was unable to find anyone who could tell him its contents, plans for publication, or even location, so in 1932 he began one of his own. He considered his work more complete and, besides, approximately one-third of his concordance was already in galley proof. ${ }^{38}$ Eby did offer to let Stewart write a brief account (" 500 words") of the history of her parents' work that he would be "glad" to incorporate into the acknowledgments. ${ }^{39}$ Van Hoesen passed copies of all this correspondence on to Stewart, who apparently declined to write anything, for when Eby's concordance began appearing in 1949, the only mention of the Trimbles' work was a seventy-three word reference to it in the "Preface." 40

If Annie and William Trimble had no luck in placing their concordance, then they were extremely fortunate in the disposition of their Whitman collection. Surprisingly, there was no mention of the collection made in William's will. ${ }^{41}$ Dorothy Stewart approached city librarian W. B. McEwan in 1927, who wrote a "Minute Paper" about how Stewart had "intimated" that the collection would go to the public library, and that she intended to assist in keeping the collection up to date by adding "any new books on the subject." McEwan described it as "a very fine gift to the Library," one containing "several very rare items," and which, as a whole, represented "the endeavours of an enthusiast who had a full knowledge of his subject." About Whitman, McEwan stated that "truly" he had "not yet come into his own, outside of America, but the day will surely come when he will be studied, not only for his poetry, but also for his philosophic outlook on life."42 And on September 9, the Town formally accepted Stewart's gift. ${ }^{43}$

In the years to come the Trimble Collection was well regarded by the Dunedin Public Library and the world. In 1940, the great Whitman collector Mrs. Frank Julian Sprague mounted an exhibit at New York University, which included a copy of the Trimble Whitman catalogue to identify it as one of the world's major collections. ${ }^{44}$ This assessment was reinforced the following year when the New York Times called the Whitman books assembled by Trimble "the largest and most important collection outside the United States."

As for Dorothy Stewart, she remained involved with Whitman and with the Trimble Collection long after the library took possession of her parents' books. ${ }^{46}$ When, in 1941, she discovered that, for the first time, users would actually be able to check out books, she wrote to the mayor and city councillors to express her concern, now that the "Reference books are lent to the public," and asked that the Trimble Collection be 
restricted to "Reference only." On October 17, the Town Clerk responded that they would be for library use only, and added: "We are very proud of this collection and are adding to it from year to year with a view to keeping it up-to-date." 47 Five years later, Stewart donated $£ 125$ in support of the Trimble collection. ${ }^{48}$ And in a 1958 directory of New Zealand book collectors, Stewart is listed as possessing a "Whitman collection of 48 volumes," which she is "willing to exhibit ... in her own home to those interested." 49

The Dunedin Public Library has always treated the Trimble Collection as a jewel in its crown. To celebrate Whitman's birthday in 1951, the library mounted an exhibition, and D. R. Grey, senior lecturer in philosophy at the University of Otago, and Dorothy Stewart made presentations. ${ }^{50}$ Similarly, the library held exhibits in 1955 and 1969 to celebrate the centenary of Leaves of Grass and the 150th anniversary of Whitman's birth, respectively. ${ }^{51}$ In the sesquicentennial year of Leaves of Grass, it mounted a major exhibition from the Trimble Collection at the University of Otago (see note 2). The library has kept the collection current by acquiring books by and about Whitman at a rate that would draw envy from most American university libraries.

Sadly, the Trimble Collection was assembled in a part of the world to which few outside people paid attention, especially the book collecting and scholarly communities. Only one thin book and a single short article discuss Whitman's reception down under, and they each cover Australia and New Zealand. ${ }^{52}$ The work of Gay Wilson Allen, who had corresponded with Stewart and who was much interested in Whitman's reception abroad, is a case study of this problem. In his 1946 Walt Whitman Handbook, he says "no information is available on the reception of [Whitman] in ... New Zealand-though ... Mr. and Mrs. W. H. Trimble compiled a concordance of Leaves of Grass." Eight years later he edited Walt Whitman Abroad, in which he merely states that Whitman had "enthusiastic friends in other parts of the British Empire" besides Great Britain itself, including the Trimbles, who had produced a concordance of Leaves described as "now in the Brown University Library." After this, 
the antipodean world disappears from the scholarly maps altogether: neither Allen's 1975 The New Walt Whitman Handbook or 1995 Walt Whitman $\mathcal{E}$ The World contains anything about Whitman in Australia or New Zealand. ${ }^{53}$ This is an unfortunate conclusion to the tale of what the Otago Daily Times claimed in 1970 was "the largest collection [of Whitman] ... in the Southern Hemisphere." 54

\section{University of South Carolina, Columbia}

\section{NOTES}

1 Betty Randle, Catalogue of the Collection of Walt Whitman Literature Presented to the Dunedin Public Library by W. H. Trimble (Dunedin: Dunedin Public Library, 1975), and Joel Myerson, Walt Whitman: A Descriptive Bibliography (Pittsburgh: University of Pittsburgh Press, 1993).

2 I returned to Dunedin in 2005 under the auspices of the Fulbright Senior Specialists program to work on this article and to curate an exhibit of materials from the Trimble Collection (see http://www.library.otago.ac.nz/exhibitions/walt_whitman/index.html). I am grateful to the Fulbright Commission for its support. Jean Strachan and especially Ian Stewart of the Dunedin Public Library provided valuable assistance in the preparation of this article.

3 Unless otherwise indicated, biographical information on the Trimbles comes from an obituary in the Otago Witness, July 19, 1927, and "Echoes of the Trimbles," Flotsam and Fetsam: Newsletter of the Friends of the Hocken Collection, no. 15 (March 1997).

4 http://www.library.otago.ac.nz/libs/hocken/index.html (January 5, 2006).

5 Clippings of these are in the Trimble Collection.

6 Catalogue of the Hocken Library, Dunedin (Dunedin: Otago Daily Times and Witness Newspapers, 1912). Trimble resigned because of what he considered an "inadequate salary" of $£ 200$ per year (Hocken to Trimble, August 25, 1912). Unless otherwise noted, all manuscript and typescript materials are in the Dunedin Public Library.

7 Henry S. Saunders to Charles N. Elliot, November 22, 1913, carbon copy.

8 Otago Witness, July 19, 1927.

9 Dr Hocken and His Historical Collection (St. Leonards [Dunedin]: [privately printed], 1926); Notes from a Lecture on Shakespeare and the Merchant of Venice ([Dunedin]: The Author, 1925); and Shakespeare's Ancient Pistol ([Dunedin]: The Author, 1926).

10 Poems by Walt Whitman (London: "Review of Reviews" Office, [1895]) appeared in W. T. Stead's The Penny Poets series. Copies of this book are in the Trimble Collection.

11 William H. Trimble, "Beginning my studies," Conservator, 19 (June 1908), 53-54. Stead's Penny Poets series is erroneously titled "Penny Post" and has been corrected here. The line is from "Song of Myself."

12 Mrs. J. W. (Dorothy) Stewart, "Walt Whitman Lecture," typescript, 1941, 13. The books referred to are Poems, ed. William Michael Rossetti (London: Chatto \& Windus, 1895), and Leaves of Grass:The Poems ofWaltWhitman [Selected], ed. Ernest Rhys (London and Newcastle-on-Tyne: Walter Scott, 1886); copies of both are in the Trimble Collec- 
tion. It is unclear which of the many biographies of Whitman published before 1898, most of which are in the Trimble Collection, is the one Trimble bought.

13 Trimble to Horace Traubel, May 24, 1903, Library of Congress; Stewart provides the May 1897 date in an annotation on Trimble's copy of the lecture; Otago Daily Times, January 23, 1899.

14 Trimble to Ellis, November 15, 1900, carbon copy. Ellis replied that "while personally sympathising with all that you say," he had "tried to hold the balance fairly" (January 2, 1901, carbon copy). Also see, for example, "The Open Court and 'Leaves of Grass,", Open Court, 14 (July 1900), 439-440, and "Surplusage or Shortage?," Conservator, 18 (April 1907), 24. Another article is attributed to Trimble in a clipping: "Casca," "Walt Whitman, Democrat," New Zealand Woman E Home Magazine, 9, no. 1 (December 11, 1922), 10-11.

15 Otago Daily Times, July 7, 1903. References to Walt Whitman and Leaves of Grass (London:Watts, 1905) will be given in the text. Stewart describes the genesis of the book as "a collection of lectures, which lack his great personal charm when merely printed. $\mathrm{He}$ used to lecture in Dunedin when I was a young girl, at a Progressive Society held in a small hall, on Sunday nights, and he always had a full house" (letter to Gay Wilson Allen, February 25, 1947, Gay Wilson Allen Papers, Duke University).

16 Horace Traubel, "Walt Whitman and Leaves of Grass," Conservator, 16 (September 1905), 107-108; letter to Trimble, October 9, 1907, in Letters of Edward Dowden and His Correspondents, [ed. Elizabeth Dickinson West Dowden and Hilda M. Dowden] (London: J. M. Dent; New York: E. P. Dutton, 1914), 353. The Otago Daily Times wished all biographers had "the sympathy, intuition, and real knowledge" for their subjects that Trimble possessed (September 29, 1905).

17 A. L. McLeod, Walt Whitman in Australia and New Zealand: A Record of His Reception (Sydney: Wentworth Press, 1964), 16; see also the Trimble Collection for additional materials documenting this relationship.

18 Traubel to Trimble, September 4, 1905. William's correspondence with Traubel is in the Horace and Annie Montgomerie Traubel Collection and Annie's is in the Charles E. Feinberg Collection, both at the Library of Congress. He was also listed as one of 113 subscribers to Traubel's unsuccessful attempt to publish a facsimile of Whitman's working copy of the 1860 Leaves, but, interestingly, Trimble himself wrote that he could not subscribe due to his "financial position" (Traubel, "A Leaves of Grass Reprint," undated clipping from the Conservator, and see Myerson, Whitman: A Descriptive Bibliography, entry A 43, note 2; Trimble to Traubel, August 15, 1902, Library of Congress). Trimble did, though, become a regular subscriber to Traubel's Conservator.

19 Charles N. Elliot, Walt Whitman as Man, Poet, and Friend: Being Autograph Pages from Many Pens (Boston: Richard G. Badger, 1915), 247-250. Elliot initially wrote on July 8, 1912, because the collector Henry S. Saunders recommended Trimble as "a most enthusiastic disciple of the Good Grey Poet" (for more on Saunders and Trimble, see below).

20 Walt Whitman and Mental Science (Melbourne: Specialty Press, 1911); according to Stewart, this was published posthumously ("Walt Whitman Lecture," 9).

21 Catalogue of a Collection of Walt Whitman Literature ("Concord," St. Leonard's [Dunedin]: [The Author, 1912]). A receipt of May 31, 1912, shows that 150 copies were printed at Trimble's expense. After receiving his own copy from Trimble, Dowden replied on June 17, 1912, that Trimble should send another copy of this "valuable guide 
to the subject" to the National Library of Ireland, which he did. The Trimble Collection has receipts from such booksellers as Goodspeed's of Boston and Sotheran of London attesting to Trimble's activities as a collector.

22 Quoted in McLeod, Walt Whitman in Australia and New Zealand, 17. Brady's copy is in the Mitchell Library in Sydney.

23 Evening Star [Dunedin] (May 31, 1919), 3. Trimble also lectured on how Whitman anticipated Charles Darwin's ideas on evolution and on "Henry Thoreau, Transcendentalist" (Otago Daily Times, May 31, 1908; Evening Star [Dunedin], July 10, 1915). In a 1908 lecture, Trimble compared the two thus: "In the man on the street Whitman saw only a comrade and a possible hero, whereas Thoreau swept the crowd aside as a mass of political corruption" ("A Few Odd Books," reported in Evening Star [Dunedin], September 9).

24 Unless otherwise noted, information about the concordance is drawn from A[nnie]. E. Trimble, "Concordance-Making in New Zealand," Atlantic Monthly, 104 (September 1909), 364-367, and William H. Trimble, "The making of a concordance," Conservator, 20 (November 1909), 133-135. Annie's article was originally accepted by the Native Companion [Melbourne], which folded before publishing it (corrected proofs for this are in the Trimble Collection). A copy of William's talk about concordance making, delivered October 12, 1909, before the Otago Institute, and highly derivative from Annie's account, is in the Trimble Collection. Two copies of the concordance exist: in the Trimble Collection and in the Saunders Collection at Brown University.

25 Isaac Hull Platt, Walt Whitman (Boston: Small, Maynard, 1904).

26 Platt to Trimble, December 18, 1903, carbon copy.

27 Platt to Trimble, February 28, 1906. He also told Trimble to "do what you can with it" and promised that "all the glory shall be yours" (Platt to Trimble, April 6, 1906).

28 Platt to Trimble, September 13, 1909 and October 12, 1909.

29 Platt to Trimble, November 26, 1910.

30 There are over one hundred letters from Saunders to Trimble in the Trimble Collection, and nearly two hundred from Trimble to Saunders in the Saunders Collection at Brown. I thank Rosemary Cullen at Brown for her assistance.

31 Saunders to Trimble, April 9, 1913.

32 Saunders to Elliot, May 25, 1915, carbon copy.

33 Saunders to Trimble, July 16, 1915; R. S. Woodward to Saunders, [November 1919], carbon copy. Woodward also noted the increases in printing costs as a factor: the Browning concordance they had priced at $\$ 30,000$ in 1914 would now cost $\$ 50,000$ to produce.

34 Stewart, "Walt Whitman Lecture," 11. Saunders discussed the history of the concordance in his remarks on May 18, 1932, when Brown formally acknowledged the collection ("A Gift of Unrivalled Whitmaniana," Brown Alumni Monthly, 33 [July 1932], 45-47).

35 Saunders to Stewart, August 31, 1932. Saunders may have had a soft spot for concording because he had considered doing one himself before being approached by Trimble (see Saunders to Trimble, May 1, 1911). 
36 Van Hoesen to Stewart, July 17, 1946.

37 Allen to Stewart, January 19, 1947.

38 Eby's concordance also included some prose writings and used a different text: rather than the $1896 \mathrm{McKay}$ printing the Trimbles used, Eby employed The Complete Writings of Walt Whitman, 10 vols. (New York and London: G.P. Putnam's Sons, 1902), which has the first book publication of numerous poems in the "Old Age Echoes" section, the personal poems that Trimble so much disliked. In the copy the Trimbles used for concording (printing C 8.1.c in Myerson, Whitman: A Descriptive Bibliography, but rebound in cloth), the lines have been numbered, duplicate words on a line marked, and dates added to indicate where their work started and stopped (811.38.S.S.No. 2).

39 Eby to Van Hoesen, July 29, 1946.

40 It appeared in five fascicles between 1949 and 1954, collected and reprinted as A Concordance to Walt Whitman's Leaves of Grass and Selected Prose Writings, ed. Edwin Harold Eby (Seattle: University of Washington Press, 1955). Stewart annotated an advertisement for Eby's book in the September 6, 1958 Statesman as follows: "What a heart break to read this."

41 "St Leonards House Was Home Of Noted Whitman Scholar," Otago Daily Times (January 20, 1970), 10.

42 W. B. McEwan, August 25, 1927.

43 Town Clerk to Stewart, September 9, 1927.

44 Stewart, "Walt Whitman Lecture," 14 (and see Sprague to Stewart, November 29, 1940). Sprague wrote Stewart on August 7, 1940, to obtain a copy of "this magnificent research work," adding that she always mentioned "the great work of the Trimbles" in her many lectures on Whitman.

45 Philip Brooks, "Notes on Rare Books," New York Times (September 7, 1941), 98.

46 She also extracted the documents relating to Whitman from the large collection of Trimble Family Papers (now at the Hocken Library) to ensure that the Dunedin Public Library received all the relevant materials.

47 Stewart to the mayor and city councillors, September 24, 1941; Town Clerk to Stewart, October 17, 1941.

48 Otago Daily Times, June 29, 1946.

49 A Roll of Book Collectors in New Zealand (Wellington: New Zealand Ex Libris and Booklovers Society, 1958), 32-33.

50 Otago Daily Times, June 1, 1951.

51 Otago Daily Times, July 2, 1955; unidentified clipping, June 7, 1969.

52 McLeod, Walt Whitman in Australia and New Zealand, and Joseph Jones, "Emerson and Whitman 'Down Under': Their Reception in Australia and New Zealand," Emerson Society Quarterly, no. 42 (First Quarter 1966), 35-46.

53 Gay Wilson Allen, Walt Whitman Handbook (Chicago: Packard, 1946), 536; Walt Whitman Abroad, ed. Allen (Syracuse: Syracuse University Press, 1954), vii; Allen, The NewWaltWhitman Handbook (NewYork: NewYork University Press, 1975); Walt Whitman E The World, ed. Allen and Ed Folsom (Iowa City: University of Iowa Press, 1995).

54 “St Leonards House Was Home Of Noted Whitman Scholar," 10. 
